\title{
D \\ COMMON OCCURRENCES OF AUTHIGENIC PYRITE CRYSTALS IN CRETACEOUS OIL SANDS AS CONSEQUENCE OF BIODEGRADATION PROCESSES

\author{
Timothy Bata $^{1}{ }^{*}$, Nuhu K. Samaila ${ }^{1}$, A.S. Maigari ${ }^{1}$, M. B. Abubakar ${ }^{1}$ \& $^{2}$ Simon Y. Ikyoive $^{1}$ \\ ${ }^{1}$ Department of Applied Geology, Abubakar Tafawa Balewa University, Bauchi, Nigeria \\ ${ }^{2}$ National Centre for Petroleum Research and Development, A.T.B.U., Bauchi, Nigeria \\ *Corresponding Author e-mail: t.p.bata00@aberdeen.ac.uk
}

This is an open access article distributed under the Creative Commons Attribution License, which permits unrestricted use, distribution, and reproduction in any medium, provided the original work is properly cited

\section{ARTICLE DETAILS}

Article history:

Received 23 August 2017 Accepted 23 September 2017 Available online 26 September 2017

Keywords:

Framboidal pyrite; Euhedral pyrite; sulfate-reducing bacteria; Cretaceous oil sands

\begin{abstract}
Ten (10) Cretaceous oil sands from different localities around the world were studied with the aim of reporting the common occurrence of authigenic pyrite crystals in them. The observed pyrite crystals (both framboid and euhedral) are restricted to the pore spaces of the studied oil sands, in close association with biodegraded oils and other authigenic minerals. Diagenetic processes in one of the studied samples triggered the transformation of framboidal pyrite crystals to octahedral pyrite crystals. This study demonstrates that geological conditions/ processes that lead to the formation of authigenic pyrite crystals in sandstones are those that favour biodegradation. Potentially, these conditions include occurrence at shallow depths $(<2000 \mathrm{~m})$, moderate reservoir temperatures that can support microbial life (temperature $<80^{\circ} \mathrm{C}$ ), availability of micro-organisms that are capable of degrading oils in the reservoir, nutrient availability (e.g., iron, nitrogen, potassium, and phosphorus), and oil volume in the reservoir. Studied framboidal pyrite crystals were observed to occur within confined spaces. The oils (organic matter) associated with the studied samples are believed to have played an important role of providing the source of spherule moulds for framboid pseudomorphs and aided the stabilization of the gel in which the framboid crystals were protected. TIC fragmentograms of the saturate fractions of the oils extracted from the studied oil sands show progressive depletion of chromatographically resolved hydrocarbons (e.g. n-alkanes, acyclic isoprenoid alkanes; alkyl benzenes, naphthalenes and phenanthrenes) relative to the unresolved hydrocarbon mixture, forming unresolved complex mixture (UCM) humps, consistent with oils that have undergone biodegradation.
\end{abstract}

\section{INTRODUCTION}

A commonly encountered authigenic mineral in organic-rich sediments is pyrite (FeS2). Pyrite is formed during shallow burial, as a result of the reaction between iron (Fe) released into solution from clay minerals and the H2S generated from the reduction of interstitial dissolved sulfate by bacteria, using sedimentary organic matter as a reducing agent and energy source $[1,2]$. In freshwater sediments, this process is limited by low concentrations of dissolved sulfate, and, as a result, little or no pyrite crystals are formed. In normal marine sediments (deposited in oxygenated bottom waters), pyrite crystal formation is limited mainly by the amount and reactivity of organic matter buried in the sediment. In marine sediments deposited in anoxic, H2S confining bottom waters, lots of pyrite crystals are formed due to the high supply of both organic matter and hydrogen sulfide. In such anoxic, H2S confining settings, pyrite formation is only limited by the reactivity of the iron minerals brought to the site of deposition $[1,2]$.

Evidences in the geological record documented occurrences of pyrite in oil reservoirs [3-7,2]. Such pyrite is believed to have a biogenic origin attributed to microbial activity since petroleum reservoirs can be attacked by specialized chemoorganotrophic sulfate-reducing bacteria which degrade the oil and precipitate pyrite during the biodegradation process.

Bacterial sulfate reduction commonly occur in geologic settings that range in temperature from 0 to about $80^{\circ} \mathrm{C}$. All sulfate-reducing bacteria cease to metabolize in geologic settings with temperatures above $80^{\circ} \mathrm{C}$ [8-11]. However, some hyperthermophilic sulfate-reducing bacteria can live at temperatures as high as about $110^{\circ} \mathrm{C}$ to $113^{\circ} \mathrm{C}[12-14]$. While bacterial sulfate reduction commonly occurs in near-surface and shallow burial diagenetic environments, evidence in the geological record have shown that thermochemical sulfate reduction commonly occurs in deep burial diagenetic settings (i.e. high-temperature environments) [15-18].

Much of the world's oil sands are Cretaceous in age. The heavy oils associated with these Cretaceous oil sands were generated as conventional light oils which later degraded into heavy oils by means of biodegradation and water washing $[19,2,20]$. An important geological factor controlling the widespread occurrence of these Cretaceous oil sands is the prevalence of Cretaceous reservoir sands with good reservoir capabilities. Deposition of these reservoir sands can be linked to the global marine transgression that occurred during the Cretaceous period which was caused by a unique greenhouse climatic condition witnessed in the Cretaceous. This extreme global warmth was a direct consequence of the high level of atmospheric CO2 that prevailed globally at that time [21,22]. This study aims to report the common occurrence of framboidal and euhedral pyrite crystals in Cretaceous oil sands.

\section{METHOD OF STUDY}

The studied oil sands were prepared as polished thin sections and examined using an ISI ABT-55 scanning electron microscope with Link Analytical 10/55S EDAX facility, so as to obtain backscattered images. Oils occurring in the studied oil sands were solvent-extracted using 93:7 (v/v) dichloromethane and methanol. The extracted oils were then separated into saturate, aromatic, and polar fractions using the ASTM D4124 test method. The saturate fractions were then examined by gas chromatography-mass spectrometry (GC-MS). The GC-MS analysis was carried out using an Agilent 6890N GC fitted with a J \& W DB-5 phase 50-m-long column linked to a 5975 MSD and a quadruple mass spectrometer working in selected-ion monitoring (SIM) mode with ionization energy of $70 \mathrm{eV}$.

Samples were injected manually using a split/splitless injector operating in splitless mode (purge $40 \mathrm{ml} \mathrm{min-} 1$ for $2 \mathrm{~min}$ ). The temperature programme for the GC oven was $80-295^{\circ} \mathrm{C}$, holding at 80 ${ }^{\circ} \mathrm{C}$ for $2 \mathrm{~min}$, rising to $10{ }^{\circ} \mathrm{C} \mathrm{min}-1$ for $8 \mathrm{~min}$ and $3{ }^{\circ} \mathrm{C} \mathrm{min}-1$ then finally holding the maximum temperature for $10 \mathrm{~min}$. Compounds were identified by comparing retention times to well-characterised materials that served as reference samples. 


\section{RESULTS}

Details of the locations and geologic ages of the studied oil sands are presented in Table 1 and Figure 1. The studied pyrite crystals occur either as spherical aggregates of minute pyritic grains forming framboids, or as disseminated euhedral pyrite crystals (Figures 2 to 6). Both the framboidal and euhedral pyrite crystals textures observed in the studied Cretaceous oil sands are generally associated with heavy oils and other authigenic minerals in the pores of the studied oil sands.

There are suggestions that the two morphologies of sedimentary pyrite (framboids and euhedra), may reflect two distinct pathways of pyrite formation. Framboids form by the oxidation of iron monosulfides by hydrogen sulfide ( $\mathrm{FeS}+\mathrm{H} 2 \mathrm{~S} \rightarrow \mathrm{FeS} 2+\mathrm{H} 2$ ). This is believed to be a very fast reaction, with framboidal pyrite crystals formed in days, and mostly occurring just below the redox boundary of strictly anoxic sediments [23-27]. The other route for pyrite formation is the polysulphide pathway, which is relatively slow and leads to the formation of isolated crystals over a period of years, usually at greater depths than those typical for framboids: $\mathrm{FeS}+\mathrm{Sx} 2-\rightarrow \mathrm{FeS} 2+\mathrm{Sx}-12-[23,1,28,26,15]$. Evidences also exist in the geological record demonstrating the possibility of pyrite recrystallization from framboidal crystals to single grains $[29,30,23]$.

\subsection{Framboidal pyrite associated with the studied oil sands}

Framboidal pyrite crystals were identified in the following studied samples: Bentheim Sandstone, Watkins Fjord Formation, Burgan Formation, Afowo Formation, Valhall Formation (Captain Sand) and the Wealden Group (Figures 2 to 4). The framboidal pyrite crystals associated with the Bentheim Sandstone has very tiny pyrite crystals which are clustered into framboids with diameters varying between 0.02 - $0.06 \mathrm{~mm}$ (Figures $2 \mathrm{a}$ and $\mathrm{b}$ ). In the studied sample of the Watkins Fjord Formation, framboidal pyrite crystals were also observed, and they vary between 0.01 to about $0.08 \mathrm{~mm}$ in diameter (Figures $2 \mathrm{c}$ and d).

The studied sample of the Burgan Formation has very tiny pyrite crystals that are clustered into framboids with diameters reaching about $0.5 \mathrm{~mm}$ (Figures $3 \mathrm{a}$ and $3 \mathrm{~b}$ ). The studied sample of Afowo Formation obtained from the Dahomey Basin of Nigeria, has very tiny pyrite crystals that can be up to $0.005 \mathrm{~mm}$ in diameter, which are clustered into framboids with diameters of more than $0.062 \mathrm{~mm}$ (Figures $3 \mathrm{c}$ and $3 \mathrm{~d}$ ). Another studied sample of the Afowo Formation has pyrite crystals that are clustered into framboids with diameters of about $0.03 \mathrm{~mm}$ (Figure 4a). The studied sample of the Valhall Formation (Captain Sand) obtained from the Western Moray Firth Basin UK, was also observed to have very tiny pyrite crystals that are clustered into framboids measuring about 0.025 $\mathrm{mm}$ in diameter $(4 \mathrm{~b})$.

Framboidal pyrite was also observed in all the studied samples of the Wealden Group obtained from the Wessex Basin in the United Kingdom. A sample of the Wealden Group from Mupe Bay locality, has various examples of framboidal pyrite crystals, measuring up to about $0.02 \mathrm{~mm}$ (Figure 4c). In the studied samples of the Wealden Group obtained from the East Lulworth Cove and West Lulworth Cove localities, the framboidal pyrite crystals are observed to have completely replaced most of the cements occurring in the pores of the oil sands and also partially replaced some of the detrital grains (Figure 4d).

\subsection{Euhedral pyrite crystals associated with the studied oil sands}

Euhedral pyrite crystals were identified in the following studied oil sands: Huitrin Formation, Burgan Formation, Mannville Formation, Tugulu Group, Valhall Formation, Captain Sand 1, Wealden Group and the Mesaverde Formation (Figures 5 and 6). Patchy euhedral pyrite crystals were identified in the studied sample of the Huitrin Formation (Figure 5a). Similarly, some euhedral octahedral pyrite crystals measuring up to $0.06 \mathrm{~mm}$ in diameter were also observed in the studied sample of the Burgan Formation (Figure 5b). Studied sample of the Mannville Formation obtained from the Western Canadian Sedimentary Basin was observed to have some euhedral pyrite crystals measuring up to about $0.08 \mathrm{~mm}$ in diameter (Figure 5c). Similarly, some euhedral pyrite crystals measuring up to about $0.01 \mathrm{~mm}$ in diameter were observed in the studied sample of the Tugulu Group obtained from Junggar Basin China (Figure 5d).

Some euhedral pyrite crystals measuring up to about $0.07 \mathrm{~mm}$ in diameter were also identified in the studied sample of the Wealden Group obtained from the East Lulworth Cove locality (Figure 6a). Some round-shaped euhedral pyrite crystals, with average diameters of about
$0.02 \mathrm{~mm}$, were also observed in the studied Wealden Group sample obtained from the Mupe Bay locality (Figure 6b). Very tiny euhedral pyrite crystals were also observed associated with bitumen in the pores of the studied sample of the Valhall Formation, Captain Sand obtained from the Western Moray Firth Basin UK (Figure 6c). Euhedral pyrite crystals occurring in the studied sample of the Mesaverde Formation obtained from Vernal, Utah USA were observed to be up to $0.03 \mathrm{~mm}$ in diameter (Figure 6d).

Table 1: Details of the locations and geologic ages of the studied oil sands with types of pyrite crystals observed

\begin{tabular}{|c|c|c|c|c|c|c|}
\hline S/No & Country & Locality & $\begin{array}{l}\text { Stratigraphic } \\
\text { name of oil } \\
\text { sand }\end{array}$ & $\begin{array}{l}\text { Geologic age } \\
\text { of oil sand }\end{array}$ & $\begin{array}{l}\text { Euhedral } \\
\text { Pyrite }\end{array}$ & $\begin{array}{c}\text { Framboidal } \\
\text { Pyrite }\end{array}$ \\
\hline 1 & Argentina & Neuquén Basin & $\begin{array}{l}\text { Huitrin } \\
\text { Formation }\end{array}$ & $\begin{array}{l}\text { Cretaceous } \\
\text { (Aptian) }\end{array}$ & $\sqrt{ }$ & \\
\hline 2 & Canada & $\begin{array}{c}\text { Western } \\
\text { Canadian } \\
\text { Sedimentary } \\
\text { Basin } \\
\end{array}$ & $\begin{array}{l}\text { Mannville } \\
\text { Group }\end{array}$ & $\begin{array}{l}\text { Cretaceous } \\
\text { (Albian) }\end{array}$ & $\sqrt{ }$ & \\
\hline 3 & China & Junggar Basin & Tugulu Group & $\begin{array}{l}\text { Cretaceous } \\
\text { (Cenomanian) }\end{array}$ & $\sqrt{ }$ & \\
\hline 4 & Germany & $\begin{array}{c}\text { Lower Saxony } \\
\text { Basin }\end{array}$ & $\begin{array}{l}\text { Bentheim } \\
\text { Sandstone }\end{array}$ & $\begin{array}{l}\text { Cretaceous } \\
\text { (Berriasian) }\end{array}$ & & $\sqrt{ }$ \\
\hline 5 & Greenland & $\begin{array}{c}\text { Kangerlussuaq } \\
\text { Basin }\end{array}$ & $\begin{array}{l}\text { Watkins Fjord } \\
\text { Formation }\end{array}$ & $\begin{array}{l}\text { Cretaceous } \\
\text { (Albian) }\end{array}$ & & $\sqrt{ }$ \\
\hline 6 & Kuwait & Arabian Basin & $\begin{array}{l}\text { Burgan } \\
\text { Formation }\end{array}$ & $\begin{array}{l}\text { Cretaceous } \\
\text { (Albian) }\end{array}$ & $\sqrt{ }$ & $\sqrt{ }$ \\
\hline 7 & Nigeria & Dahomey Basin & $\begin{array}{l}\text { Afowo } \\
\text { Formation }\end{array}$ & $\begin{array}{l}\text { Cretaceous } \\
\text { (Turonian) }\end{array}$ & & $\sqrt{ }$ \\
\hline 8 & $\begin{array}{l}\text { United } \\
\text { Kingdom } \\
\text { (UK) }\end{array}$ & $\begin{array}{l}\text { Western Moray } \\
\text { Firth Basin }\end{array}$ & $\begin{array}{l}\text { Valhall } \\
\text { Formation } \\
\text { (Captain } \\
\text { Sand) }\end{array}$ & $\begin{array}{l}\text { Cretaceous } \\
\text { (Aptian) }\end{array}$ & $\sqrt{ }$ & $\sqrt{ }$ \\
\hline 9 & $\begin{array}{l}\text { United } \\
\text { Kingdom } \\
\text { (UK) }\end{array}$ & Wessex Basin & $\begin{array}{l}\text { Wealden } \\
\text { Group }\end{array}$ & $\begin{array}{l}\text { Cretaceous } \\
\text { (Valanginian) }\end{array}$ & $\sqrt{ }$ & $\sqrt{ }$ \\
\hline 10 & USA & Vernal, Utah & $\begin{array}{l}\text { Mesaverde } \\
\text { Formation }\end{array}$ & $\begin{array}{l}\text { Cretaceous } \\
\text { (Albian) }\end{array}$ & $\sqrt{ }$ & \\
\hline
\end{tabular}

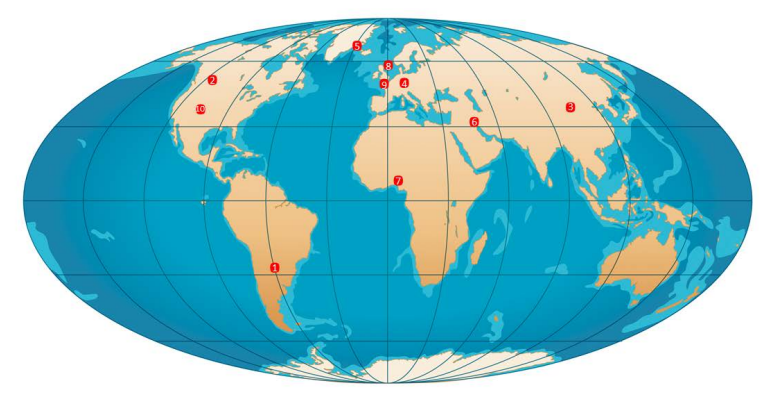

Figure 1: Present-day world paleogeographic map showing approximate locations of the studied Cretaceous oil sands. Details of studied localities are presented in Table 1

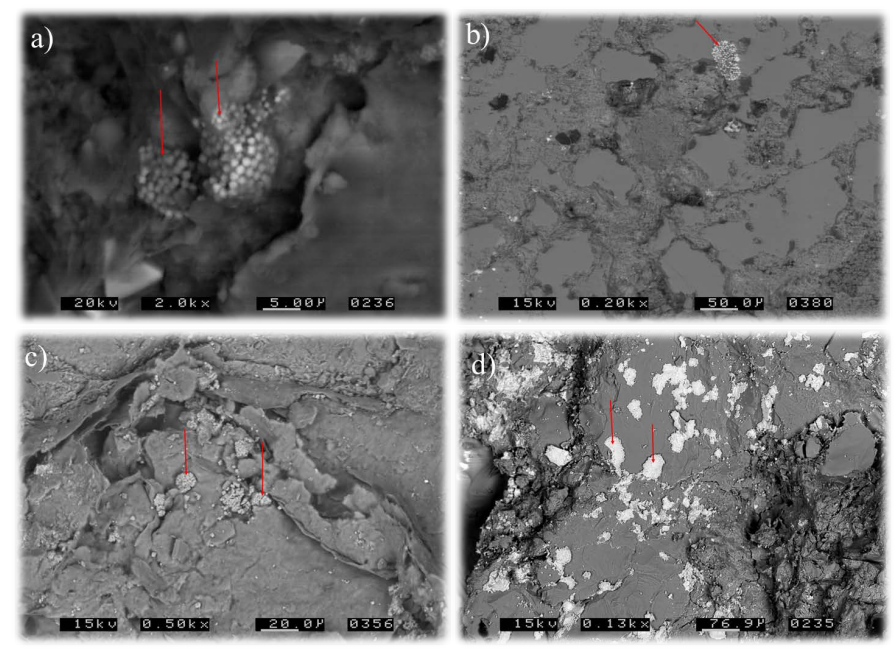

Figure 2 (a and b): Backscattered SEM images showing framboidal pyrite (red arrows) associated with the Bentheim Sandstone, Lower Saxony Basin, Germany. (c \& d) Backscattered SEM images showing framboidal pyrite (red arrows) associated with the Watkins Fjord Formation, Kangerlussuaq Basin, Greenland. 

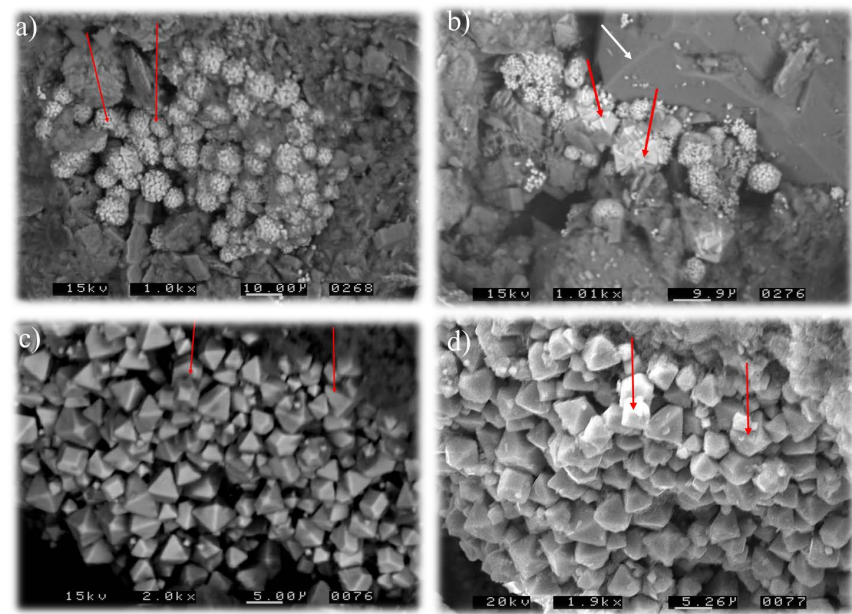

Figure 3 (a and b): Backscattered SEM images showing framboidal pyrite (red arrows) associated with the Burgan Formation, Arabian Basin, Kuwait. Note the transformation of spherical pyrite microcrystals to octahedral pyrite crystals (red arrows) and quartz overgrowth (white arrow) in 3 b. (c \& d) Backscattered SEM images showing framboidal pyrite (red arrows) associated with the Afowo Formation Dahomey Basin, Nigeria.
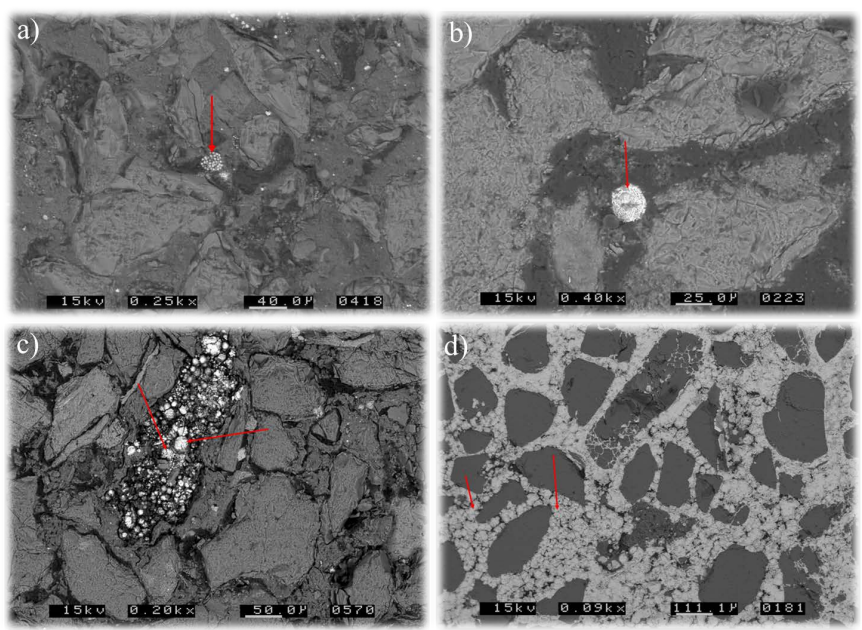

Figure 4:(a) Backscattered SEM image showing framboidal pyrite associated with the Afowo Formation, Dahomey Basin, Nigeria (b)Backscattered SEM image showing framboidal pyrite (red arrows) associated with the Valhall Formation (Captain Sand), Western Moray Firth Basin UK. (c \& d) Backscattered SEM images showing framboidal pyrite (red arrows) associated with the Wealden Group Wessex Basin, UK.
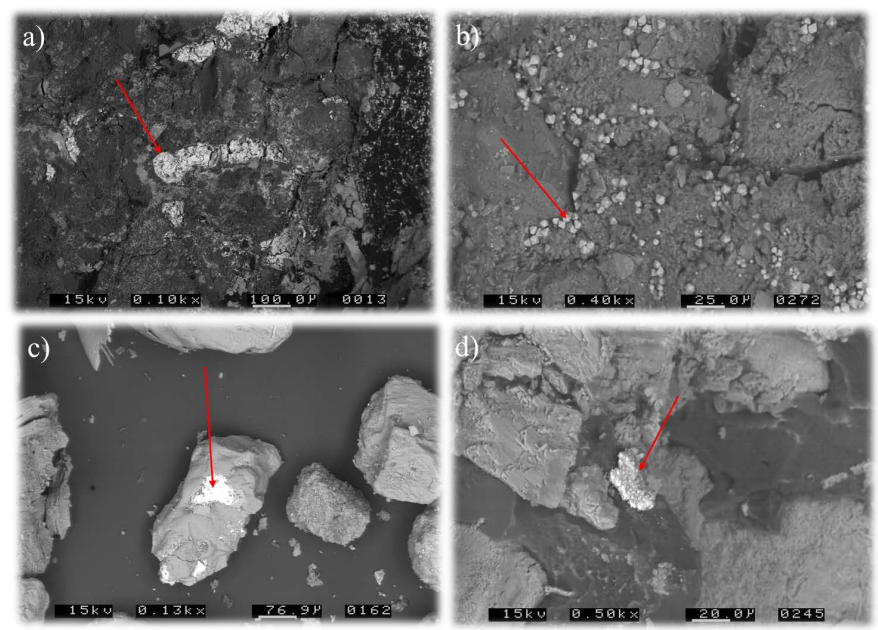

Figure 5: Backscattered SEM images of euhedral pyrite (a) Huitrin Formation, Neuquén Basin, Argentina (b) Burgan Formation, Arabian Basin, Kuwait (c) Mannville Formation, Western Canada Sedimentary Basin and (d) Tugulu Group, Junggar Basin, China.
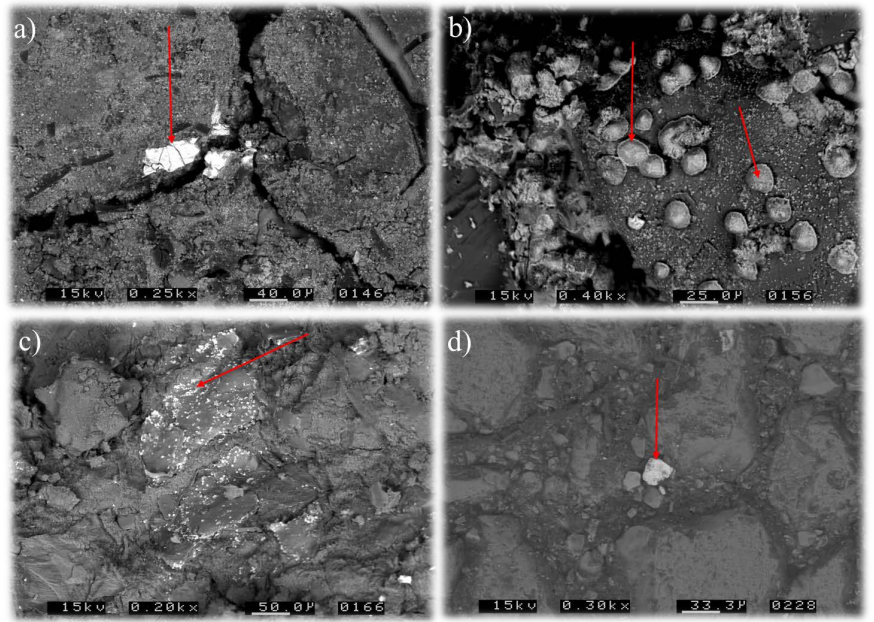

Figure 6: Backscattered SEM images of euhedral pyrite (a) Wealden Group (elc), Wessex Basin, UK. (b) Wealden Group (mbm), Wessex Basin, UK. (c) Valhall Formation, Captain Sand 1, Moray Firth Basin, UK. And (d) Mesaverde Formation, Uinta Basin, USA.

\subsection{Oil Geochemistry (Evidence of biodegradation)}

GC-MS Fragmentograms showing the total ion current (TIC) of the saturate fractions of the studied oils are also presented in Figure 7. The TICs show the presence of unresolved complex mixture (UCM) humps. This is a common characteristic of oils that have undergone biodegradation [31-33,7,19,2].
(1)

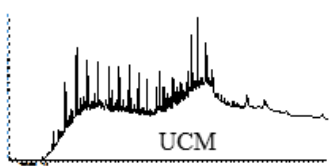

(2)

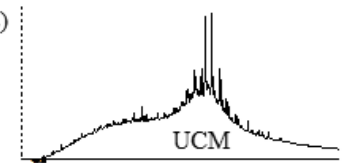

(3) :

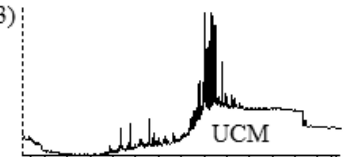

(4)

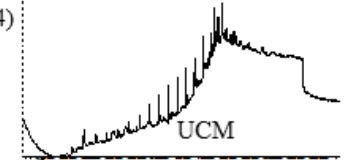

(5)

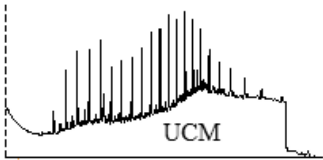

(6)

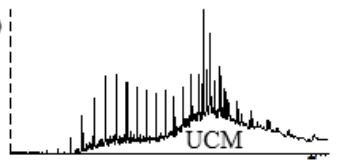

(7)

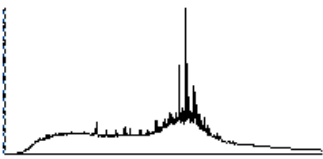

(8)

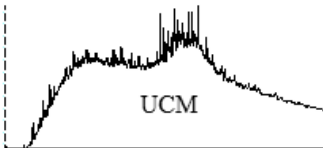

(9)

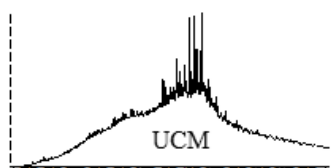

(10)

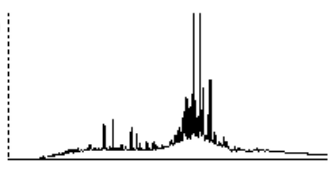

Figure 7: TIC fragmentograms of oils extracted from the studied oil sands showing progressive depletion of chromatographically resolved hydrocarbons (e.g. n-alkanes, acyclic isoprenoid alkanes; alkyl benzenes, naphthalenes and phenanthrenes) relative to the unresolved hydrocarbon mixture, forming an unresolved complex mixture (UCM) humps, consistent with oils that have undergone biodegradation. Details of sample names and locations are as presented in Table 1 and Figure 1.

\section{DISCUSSION}

The studied oil sands are observed to be ideal environments for the growth of authigenic pyrite crystals because they contain sulfur (derived from both the heavy oils associated with the oil sands and fossil seawater sulfate trapped within the sediments), reactive iron (derived from clay minerals associated with the oil sands) and abundant organic matter which have source of energy for sulfate-reducing bacteria and providing 
he source of spherule moulds for framboid pseudomorphs.

Framboidal pyrite crystals were identified in the studied oil sands obtained from the Lower Saxony Basin (Germany), Arabian Basin (Kuwait), Dahomey Basin (Nigeria), Western Moray Firth Basin (UK) and Wessex Basin (UK) (Figures 2 to 4). Different origins have been inferred for framboidal pyrite crystals, including a purely inorganic origin, based on laboratory synthesis and occurrences in magmatic rocks, framboid formation through indirect biogenic processes, and a direct biogenic process of framboid formation [23,34,28,35,36,37]. Occurrence of the studied framboidal pyrite crystals in close association with biodegraded oils in the pores of the oil sands suggests that they were formed as part of the biodegradation processes that occurred in the oil sands.

Framboidal pyrite crystals are known to have limited stability in the absence of organic matter [38,29]. This also implies that organic matter plays a very important role in framboidal pyrite formation. Framboidal pyrite crystals are known to occur within confined spaces such as foraminifera tests, diatom frustules, polychaete tubes and plant cells (Figures 2 to 4 ) $[39,40,23]$. The organic matter associated with the studied oil sands is believed to have played an important role of providing the source of spherule moulds for framboid pseudo morphs and the stabilization of the gel in which the framboid crystals were protected.

Disseminated euhedral pyrite crystals and pyrite cements have also been identified in some of the studied oil sands obtained from the Neuquén Basin (Argentina), Arabian Basin (Kuwait), Western Canadian Sedimentary Basin, Wessex Basin (UK) and Vernal, Utah (USA) (Figs 5 \& 6). Pyrite crystals with intermediate textures between framboid and euhedral textures have also been observed in the studied sample of the Burgan Formation obtained from the Arabian Basin, Kuwait (Figure 3b). This transformation of spherical pyrite microcrystals to octahedral crystals is believed to be the effect of diagenesis. This is supported by the presence of quartz overgrowth also observed in the studied sample of the Burgan Formation (Figure 3b) which presently occurs at a depth of about 2,456 $\mathrm{m}$ that supports such diagenetic processes. Observed pyrite crystals with an intermediate texture observed in the studied sample of the Burgan Formation (Figure $3 \mathrm{~b}$ ) recrystallized from the framboidal pyrite associated with the Burgan Formation. The transformed or recrystallized pyrite crystals are observed to be closely packed with nearly homogeneous crystals, having only tiny spaces between the individual crystals, thus retaining the impression of a framboidal texture (Figure 3b).

As mentioned earlier, occurrence of the studied pyrite crystals with biodegraded oils in the pores of the studied oil sands suggests that their origin is closely linked to the biodegradation processes occurring in the oil sands. Evidences of biodegradation in the studied oil sands have been presented in Figure 7. Petroleum biodegradation is known to cause the progressive depletion of chromatographically resolved hydrocarbons (e.g. n-alkanes, acyclic isoprenoid alkanes; alkyl benzenes, naphthalene's and phenanthrenes) relative to the unresolved hydrocarbon mixture, forming an unresolved complex mixture (UCM) humps on the TIC fragmentogram as observed in Figure 7.

The studied Cretaceous oil sands are ideal sites for biodegradation and authigenic pyrite formation because they commonly occur at shallow depths $(<2000 \mathrm{~m})$, are usually cool, and contain essential nutrients that supports microbial life. Mean $\delta 34 \mathrm{~S}$ data presented by a researcher has demonstrated that pyrite crystals associated with some Cretaceous oil sands are isotopically light, with isotopic fractionation between these pyrites crystals and contemporary seawater sulfate exceeding the maximum known kinetic isotope fractionation of $\sim 20 \%$ o that is possible from non-biogenic mechanisms. This therefore strongly implies that both framboidal and euhedral pyrite crystals occurring in Cretaceous oil sands precipitated from an open system by means of microbial sulfate reduction as part of the biodegradation process.

\section{SUMMARY AND CONCLUSION}

This study reports the common occurrence of authigenic pyrite crystals in Cretaceous oil sands. The processes of these pyrite crystal formation in the studied oil sands depend on the availability of organic matter, sulphur and iron. The organic matter needed for pyrite formation is always readily available in the bitumen associated with the oil sands, while sulphur can be derived from both the bitumen and fossil seawater sulphate, trapped within the sediments. The iron needed for pyrite formation in the oil sands were derived from clay minerals associated with the studied sandstones. Specifically, this study demonstrates the following:

i. The studied pyrite crystals (both framboids and euhedral) are restricted to the pore spaces of the studied oil sands, in close association with biodegraded oils, suggesting that their origin is closely linked to the biodegradation processes occurring in the studied oil sands. TIC Fragmentograms of the saturate fractions of the oils extracted from the studied oil sands show the presence of unresolved complex mixture (UCM) humps, consistent with oils that have undergone biodegradation.

ii. Examples of framboidal pyrite crystals were identified in the studied Cretaceous oil sands obtained from the Lower Saxony Basin (Germany), Arabian Basin (Kuwait), Dahomey Basin (Nigeria), Western Moray Firth Basin (UK) and Wessex Basin (UK). These framboidal pyrite crystals are observed to occur within confined spaces with the organic matter associated with the studied oil sands playing the important role of providing the source of spherule moulds for framboid pseudomorphs and stabilization of the gel in which the framboid crystals are protected.

iii. Examples of disseminated euhedral pyrite crystals were identified in the studied oil sands obtained from the Neuquén Basin (Argentina), Arabian Basin (Kuwait), Western Canadian Sedimentary Basin, Wessex Basin (UK) and Vernal, Utah (USA). These euhedral pyrite crystals are also associated with biodegraded oils in pores of the studied oil sands.

iv. Examples of pyrite crystals with intermediate textures between framboid and euhedral were also identified in the studied sample of the Burgan Formation obtained from the Arabian Basin Kuwait. This transformation of spherical pyrite microcrystals to octahedral crystals is believed to be the effect of diagenesis as supported by the evidence of quartz overgrowth observed in the studied sample of the Burgan Formation.

\section{ACKNOWLEDGEMENTS}

The first author is thankful to the Petroleum Technology Development Fund of Nigeria for sponsoring his PhD research at the University of Aberdeen, and the management of Abubakar Tafawa Balewa University Bauchi, Nigeria, for permitting him to proceed on study leave. The authors acknowledge the British Geological Survey for providing core samples of the Captain Sand used in this study. They also acknowledge the help and support received from the Nigerian Geological Survey Agency, Akure during the field work in Dahomey Basin, Nigeria.

\section{REFERENCES}

[1] Berner, R. A. 1984. Sedimentary pyrite formation: an update. Geochimica et Cosmochimica Acta, 48, 605-615.

[2] Bata, T. 2016. Geochemical Consequences of Cretaceous Sea Level Rise. Unpublished PhD thesis submitted to the Department of Geology and Petroleum Geology, University of Aberdeen. http://ethos.bl.uk/ OrderDetails.do?uin=uk.bl.ethos.690589

[3] Mason, G. M., Kirchner, G. 1992. Authigenic pyrite: evidence for a microbial origin of tar sand. Fuel, 71,1403-1405.

[4] Wolicka, D., Borkowski, A., Dobrzyński, D. 2010. Interactions between microorganisms, crude oil and formation waters. Geomicrobiology Journal, 27, 43-52.

[5] Fallick, A. E., Boyce, A. J., McConville, P. 2012. Sulphur stable isotope systematics in diagenetic pyrite from the North Sea hydrocarbon reservoirs revealed by laser combustion analysis. Isotopes in Environmental and Health Studies, 48,144-165.

[6] Bata, T., Parnell, J. 2014. A Neoproterozoic petroleum system in the Dalradian Supergroup, Scottish Caledonides. Journal of the Geological Society, 171, 145-148.

[7] Parnell, J., Bellis, D., Feldmann, J., Bata, T. 2015. Selenium and 
tellurium enrichment in palaeo-oil reservoirs. Journal of Geochemical Exploration, 148, 169-173.

[8] Postgte J.R. 1984. The Sulfate-reducing Bacteria. Cambridge University Press, Cambridge. 2nd ed. 208 pp.

[9] Ehrlich, H.L., 1990. Geomicrobiology. 2nd ed. Marcel Dekker, New York. 646.

[10] Machel, H.G., Foght, J. 2000. Products and depth limits of microbial activity in petroliferous subsurface settings. In: Riding, R., Awramik, S.M. (Eds.). Microbial Sediments,105-120. Springer, Berlin.

[11] Machel, H.G. 2001. Bacterial and thermochemical sulfate reduction in diagenetic settings-old and new insights. Sedimentary Geology, $140,143-175$.

[12] Jørgensen, B.B., Isaksen, M.F., Jannasch, H.W. 1992. Bacterial sulfate reduction above $100 \mathrm{C}$ in deep-sea hydrothermal vent sediments. Science, 258, 1756-1757.

[13] Stetter, K.O., Huber, R., Blöchl, E., Kurr, M., Eden, R.D., Fielder, M., Vance, I. 1993. Hyperthermophilic archaea are thriving in deep North Sea and Alaskan oil reservoirs. Nature, 365, 743-745.

[14] Elsgaard, L., Isaksen, M. F., Jørgensen, B. B., Alayse, A. M., and Jannasch, H. W. 1994. Microbial sulfate reduction in deep-sea sediments at the Guaymas Basin hydrothermal vent area: influence of temperature and substrates. Geochimica et Cosmochimica Acta, 58, $3335-3343$

[15] Anderson, J.H., Machel, H.G. 1988. The Upper Devonian Nisku reef trend in central Alberta, Geldsetzer, H.H.J., James, N.P., Tebbutt, G.E. (Eds.). Canadian Society of Petroleum Geologists, 13, 391-398.

[16] Hutcheon, I., Krouse, H.R., Abercrombie, H. 1995. Geochemical transformations of sedimentary sulfur: controls of the origin and distribution of elemental sulfur, $\mathrm{H} 2 \mathrm{~S}$ and $\mathrm{CO} 2$, in Paleozoic reservoirs of western Canada. In: Vairavamurthy, M.A., Schoonen, M.A.A.(Eds.), Geochemical Transformations of Sedimentary Sulfur. ACS Symposium Series, 612, 426-438.

[17] Worden, R.H., Smalley, P.C., Oxtoby, N.H. 1995. Gas souring by thermochemical sulfate reduction at $1408 \mathrm{C}$. American Association of Petroleum Geologists, 79, 854-863.

[18] Manzano, B.K., Fowler, M.G., Machel, H.G. 1997. The influence of thermochemical sulfate reduction on hydrocarbon composition in Nisku reservoirs, Brazeau River area, Alberta, Canada. Organic Geochemistry, 27, 507-521.

[19] Bata, T., Parnell, J., Samaila, N. K., Abubakar, M. B., Maigari, A. S. 2015. Geochemical evidence for a Cretaceous oil sand (Bima oil sand) in the Chad Basin, Nigeria. Journal of African Earth Sciences, 111, 148-155.

[20] Hein, Frances J. 2017. Geology of bitumen and heavy oil: An overview. Journal of Petroleum Science and Engineering 154, 551-563.

[21] Skelton, P.W. 2003. The Cretaceous world. Cambridge University Press, London.

[22] Wang, C.S., Huang, Y.J., Hu, X.M., Li, X.H. 2004. Cretaceous oceanic red beds: implications for paleoclimatology and paleoceanography. Acta Geologica Sinica (English Edition) ,78, 873-877.

[23] Sawlowcz, Z. 1993. Pyrite framboids and their development: a new conceptual mechanism. Geologische Rundschau, 82, 148-156.

[24] Rickard, D., Schoonen, M.A.A., Luther III, G.W. 1995. Chemistry of iron sulfides in sedimentary environments. In: Vairavamurthy, M.A.,
Schoonen, M.A.A. (Eds.), Geochemical Transformations of Sedimentary Sulfur. American Chemical Society Symposium Series, 612, 168-193.

[25] Rickard, D. 1997. Kinetics of pyrite formation by the H2S oxidation of iron(II) monosulfide in aqueous solutions between 25 and $125{ }^{\circ} \mathrm{C}$ : the rate equation. Geochimica et Cosmochimica Acta, 61, 115-134.

[26] Butler, I.B., Rickard, D. 2000. Framboidal pyrite formation via the oxidation of iron(II) monosulfide by hydrogen sulphide. Geochimica et Cosmochimica Acta, 64, 2665-2672.

[27] Álvarez-Iglesias, P., Rubio, B. 2012. Early diagenesis of organicmatter-rich sediments in ría environment: Organic matter sources, pyrites morphology and limitation of pyritization at depth. Estuarine, Coastal and Shelf Science, 100, 113-123.

[28] Wilkin, R.T., Barnes, H.L. 1997. Pyrite formation in an anoxic estuarine basin. American Journal of Science, 297, 620-650.

[29] Ostwald, J., England, B. M. 1977. Notes on framboidal pyrite from Allandale New South Wales, Australia. Mineral Depos, 12, 111-116.

[30] Sawlowicz, Z. 1987. Framboidal pyrite from the metamorphic Radzimowice Schists of Stara Gora (Lower Silesia, Poland). Mineral Polon, 18, 57-67.

[31] Gouch, M. A., Rhead, M. M., Rowland, S. J. 1992. Biodegradation studies of unresolved complex mixtures of hydrocarbons: model UCM hydrocarbons and the aliphatic UCM. Organic Geochemistry, 18, 17-22.

[32] Frysinger, G.S., Gaines, R.B., Xu, L., Reddy, C.M. 2003. Resolving the unresolved complex mixture in petroleum-contained sediments. Environmental Science and Technology, 37,1653-1662.

[33] Ventura, G. T., Kenig, F., Reddy, C. M., Frysinger, G. S., Nelson, R. K., Van Mooy, B. and Gaines, R. B. 2008. Analysis of unresolved complex mixtures of hydrocarbons extracted from Late Archean sediments by comprehensive two-dimensional gas chromatography (GC× GC). Organic Geochemistry, 39, 846-867.

[34] Lugheed, M. S., Mancuso, J. J. 1973. Hematite framboids in the Negaunee Iron Formation, Michigan: evidence for their biogenic origin. Economic Geology, 68, 202-209.

[35] Rigby, P. A., Dobos, S. K., Cook, F. J., Goonetilleke, A. 2006. Role of organic matter in framboidal pyrite oxidation. Science of the Total Environment, 367, 847-854.

[36] Ding, H., Yao, S., Chen, J. 2014. Authigenic pyrite formation and reoxidation as an indicator of an unsteady-state redox sedimentary environment: Evidence from the intertidal mangrove sediments of Hainan Island, China. Continental Shelf Research, 78, 85-99.

[37] Tian, L., Tong, J., Algeo, T. J., Song, H., Song, H., Chu, D., Shi, L., Bottjer, D. J. 2014. Reconstruction of Early Triassic ocean redox conditions based on framboidal pyrite from the Nanpanjiang Basin, South China.Palaeogeography, Palaeoclimatology, Palaeoecology, 412, 68-79.

[38] Love, L. G., Brockley, H. 1973. Peripheral radial texture in framboids of polyframboidal pyrite. Fortschr Miner 50, 264-269.

[39] Thomsen, E., Vorren, T. 0. 1984. Pyritization of tubes and burrows from Late Pleistocene continental shelf sediments off North Norway. Sedimentology, 31, 481-492.

[40] McNeil, D. H. 1990. Stratigraphy and paleoecology of the Eocene Stellarima Assemblage Zone (pyrite diatom steinkerns) in the Beaufort-Mackenzie Basin, Arctic Canada. Bulletin of Canadian Petroleum Geology, 38,17-27. 